\title{
Life cycle and settlement of an Australian isolate of Ichthyophthirius multifiliis Fouquet, 1876 from rainbow trout
}

\author{
James M. Forwood ${ }^{1}$, James O. Harris ${ }^{1}$, Matt Landos ${ }^{2}$ and Marty R. Deveney ${ }^{3,4}$ \\ ${ }^{1}$ School of Biological Sciences, Flinders University, Adelaide, South Australia, Australia; \\ ${ }^{2}$ Future Fisheries Veterinary Services Pty Ltd, East Ballina, New South Wales, Australia; \\ ${ }^{3}$ South Australian Research and Development Institute (SARDI), West Beach, South Australia, Australia; \\ ${ }^{4}$ Marine Innovation South Australia (MISA), West Beach, South Australia, Australia
}

\begin{abstract}
Ichthyophthirius multifiliis Fouquet, 1876, a ciliate parasite, is a cosmopolitan and problematic parasite of cultured freshwater fish. Each geographical isolate of I. multifiliis has variations in life cycle timing under different abiotic water conditions, such as temperature and salinity. We assessed the effects of salinity and temperature on the development and the preferred settlement site of a temperate Australian isolate of I. multifiliis. The time until theront release was significantly different between each temperature; development time was longest at $5^{\circ} \mathrm{C}$ with a mean time of $189 \mathrm{~h}$ and decreased to a mean time of $11.7 \mathrm{~h}$ at $30^{\circ} \mathrm{C}$. At $5^{\circ} \mathrm{C}$ our isolate produced a mean of 267 theronts per tomont, which increased to a mean of 493 theronts at $25^{\circ} \mathrm{C}$ and reduced to a mean of 288 theronts at $30^{\circ} \mathrm{C}$. Theront length showed an inverse relationship to temperature; mean length was $62 \mu \mathrm{m}$ at $5^{\circ} \mathrm{C}$ and $41 \mu \mathrm{m}$ at $30^{\circ} \mathrm{C}$. Our isolate reproduced faster at all temperatures and a greater sensitivity to salinity than all reported profiles for temperate isolates. Parasite abundance was highest on the dorsal region of the fish. An accurate understanding of temperature-life cycle information and optimal region to sample for surveillance will aid in the development of specific management plans for the Australian isolate of $I$. multifiliis, facilitating the strategic timing of treatments.
\end{abstract}

Keywords: Ichthyophthirius multifiliis, disease management, temperature, salinity

Ichthyophthirius multifiliis Fouquet, 1876, a ciliate parasite, has worldwide distribution (Nigrelli et al. 1976) and is a problematic parasite of cultured freshwater fish worldwide (Schäperclaus 1992, Dickerson and Dawe 1995, Picón-Camacho et al. 2012). The wide geographical distribution of I. multifiliis is primarily due to the translocation of infected host species, the low host specificity of the pathogen and its capacity to reproduce rapidly (Matthews 2005). The entry of I. multifiliis to Australia probably occurred multiple times but was first introduced on imported ornamental exotic fish (Ashburner 1976). The first I. multifiliis outbreak on an Australian trout farm was associated with the release of infected goldfish Carassius auratus auratus (Linnaeus) in Tasmania and the parasite was introduced to Victoria with imported carp Cyprinus carpio Linnaeus (see Butcher 1947).

The life cycle of I. multifiliis is direct, with four stages: the parasitic trophont resides in the host's epidermis and develops into the tomont, which leaves the host and encysts in the aquatic environment. The tomont undergoes rapid division, usually in the cyst, into daughter cells, the tomites, which develop into theronts, the free swimming in- fective stage that locates the host, penetrates the epidermis and develops into a trophont (MacLennan 1942, Matthews 2005). The development period is influenced by water temperature and salinity (Bauer 1958, Wagner 1960, Noe and Dickerson 1995, Aihua and Buchmann 2001). Buschkiel (1910) and Nigrelli et al. (1976) suggested that subtle variations in cell morphology and temperature preferences of different isolates in different climatic zones could be due to the presence of different physiological strains of the parasite. Different strains of I. multifiliis are characterised by GPI-anchored membrane proteins (referred to as immobilisation antigens or i-antigens): there are five i-antigen serotypes (Dickerson and Clark 1996). Ecologically distinct isolates are influenced differently by temperature and salinity (Aihua and Buchmann 2001).

Which strain(s) occur in Australia and the effect of temperature and salinity on development of Australian isolates was unknown. Detailed knowledge of the life cycle is required to facilitate effective management of the parasite and to determine why management programs were ineffective. We therefore investigated life cycle parametres and parasite settlement of an isolate of I. multifiliis from Aus- 
tralian trout farms, focusing on temperature and salinity, and comparing the data to other isolates.

\section{MATERIALS AND METHODS}

\section{Culture of parasites}

Rainbow trout, Oncorhynchus mykiss (Walbaum), infected with Ichthyophthirius multifiliis were obtained from Snobs Creek Hatchery (Department of Environment and Primary Industries, Victoria, Australia) during the Austral summer of 2012. Infected fish were transferred to Flinders University and held in aerated aquaria (200 1) containing recirculating dechlorinated municipal water (hardness $145 \mathrm{mg} / \mathrm{l}$, alkalinity $20 \mathrm{mg} / \mathrm{l}$ as $\mathrm{CaCO}_{3}, \mathrm{pH} 6.1$ ), continuously filtered with biofilters. The tanks were maintained at $17 \pm 1{ }^{\circ} \mathrm{C}$, with light/dark periods set artificially at $12: 12 \mathrm{~h}$. The parasites were allowed to multiply in the aquaria. Any fish that showed signs of substantially affected health were removed and euthanased and replaced with naïve uninfected rainbow trout.

\section{Isolation of tomonts}

Temperature and salinity experiments were based on the method of Aihua and Buchmann (2001). Rainbow trout with visible trophonts were euthanased with an overdose (40 ml 10001 bath) of Aqui-S ${ }^{\circledR}$ (50\% isoeugenol; Aqui-S, Lower Hutt), rinsed, and placed into a $600 \mathrm{ml}$ beaker containing $80 \mathrm{ml}$ aquarium water. Trophonts were allowed to dislodge and were collected $30 \mathrm{~min}$ after adding the fish using a $200 \mu$ pipette. Eight trophonts were transferred to each well of a 24-well multidish (Corning ${ }^{\circledR}$, New York, USA) containing $2 \mathrm{ml}$ of $0.2 \mu \mathrm{m}$ filtered (Sartorius Stedim Pty Ltd., Dandenong South, Victoria, Australia) water from the infection tank. At the start of each experiment eight trophonts were fixed in 10\% neutral-buffered formalin (NBF) and measured.

\section{Temperature trials}

Multidish plates containing trophonts in wells were placed into incubators at $5,9,12,17,21,25$ and $30^{\circ} \mathrm{C}$, and inspected regularly using a dissecting microscope (20-40× magnification) to assess if theronts had been released. The time to the first theront release and number of tomonts that did not develop into tomocysts were recorded. Following the release of all theronts, a drop of 10\% neutral buffered formalin (NBF) and Lugol's iodine were added to each well and the number of theronts counted using a dissecting microscope. From each well, a sample was pipetted onto a slide and five randomly selected theronts were measured using a compound microscope with a calibrated ocular eyepiece (400× magnification). The experiments were repeated three times at each temperature.

\section{Salinity trials}

Multidish plates containing trophonts in wells with sodium chloride (Merck ${ }^{\circledR}$, Kilsyth, Victoria, Australia, batch ref. MJ6M562652) added at 1, 3, 5, and $7.5 \mathrm{~g} / 1$ were incubated at $12^{\circ} \mathrm{C}$ and $17^{\circ} \mathrm{C}$ in separate trials and regularly inspected under a dissection microscope (20-40× magnification). Control groups contained wells with filtered water without sodium chloride. The protocol then followed that for temperature. The experiments were repeated three times at each salinity and temperature.

\section{Detection of Ichthyophthirius multifiliis}

Twenty five rainbow trout with a mean length of $6.8 \mathrm{~cm}$ (range 5.5-9.1 cm) were randomly selected from five different trout farms. For each fish parasite intensity was determined for four different regions: the dorsal, ventral, lateral left and right by skin scrape using a sterile scalpel. Skin scrapes were placed onto microscope slides and viewed under compound microscope (magnification $100 \times$ ) and the number of I. multifiliis in each region was recorded.

\section{Statistical analysis}

Prior to analysis, normality of the data was tested using the Kolmogorov-Smirnov test and variances were tested using Levene's test. To achieve homoscedasticity, the data for the mean time to theront production, the mean theront length and settlement site were $\log _{10}$ transformed. Differences in the mean time taken to produce theronts between temperatures and salinities, the number of theronts produced at each temperature and salinity, the length of the theronts produced and settlement site were analysed using a one-way ANOVA. Where significant differences were detected in the ANOVAs, post hoc comparisons were made using Tukey's tests. The statistical analysis was performed using IBM SPSS Statistics 20.0 and significance for all tests was judged at $\mathrm{P}<0.05$.

\section{RESULTS}

\section{Temperature trials}

The tomonts used during the temperature trials had a mean diameter of $323 \mu \mathrm{m}$ (range 203-503 $\mu \mathrm{m}$ ). Temperature had a significant effect on the time tomonts took to release theronts (one-way ANOVA: $\mathrm{F}_{6,135}=3117.6$, $\mathrm{P}<0.001)$. The development time was proportional to temperature and significantly different between each temperature (Table 1). There was a significant difference in the mean number of theronts produced by each tomocyst between each temperature (one-way ANOVA: $\mathrm{F}_{6,135}=16.223$, $\mathrm{P}=0.001)$. Theront production was lower in cold water, significantly increasing with a higher water temperature peaking at $25^{\circ} \mathrm{C}$, after which theront production decreased significantly (Table 1). Theront length showed an inverse relationship to the incubation temperature and was significantly different between each temperature (one-way ANOVA: $\left.\mathrm{F}_{6,133}=26.204, \mathrm{P}<0.001\right)($ Table 1$)$.

\section{Salinity trials}

The tomonts used during the salinity trials had a mean diameter of $284 \mu \mathrm{m}$ (range 175-380 $\mu \mathrm{m}$ ). There was a significant difference in the viability of tomonts between all salinities at $12^{\circ} \mathrm{C}$ (one-way ANOVA: $\mathrm{F}_{4,10}=62.222$, $\mathrm{P}<0.001$ ) and $17^{\circ} \mathrm{C}$ (one-way ANOVA F ${ }_{4,10}=61.100$, $\mathrm{P}<0.001)$. When exposed to $7.5 \mathrm{~g} / 1$ sodium chloride at $12^{\circ} \mathrm{C}$ and $17^{\circ} \mathrm{C}$, tomonts ceased movement within $1 \mathrm{~h}$, with no division or formation of tomocysts. Tomonts exposed to $5 \mathrm{~g} / \mathrm{l}$ sodium chloride were unable to produce theronts, although $29 \%$ and $33 \%$ were able to form a cyst wall and initiate division at $12^{\circ} \mathrm{C}$ and $17^{\circ} \mathrm{C}$, respectively. There was no significant difference in viability of tomonts exposed to $1 \mathrm{~g} / 1$ and controls at $12^{\circ} \mathrm{C}$ (Table 2 ) and $17^{\circ} \mathrm{C}$ (Table 3). 
Table 1. Temperature-dependant development of tomonts of Ichthyophthirius multifiliis $(\mathrm{n}=24)$ at different water temperatures. Values are expressed as mean with range in parentheses. Different superscripts indicate significant differences using Tukey's analysis $(\mathrm{P}<0.05)$.

\begin{tabular}{ccccc}
\hline Temperature $\left({ }^{\circ} \mathrm{C}\right)$ & $\begin{array}{c}\text { Time from tomont to } \\
\text { theront (hours) }\end{array}$ & $\begin{array}{c}\text { Tomonts developing } \\
\text { into tomocysts }(\%)\end{array}$ & $\begin{array}{c}\text { Number of theronts } \\
\text { from one tomocyst }\end{array}$ & $\begin{array}{c}\text { Length of theronts } \\
(\mu \mathrm{m})\end{array}$ \\
\hline 5 & $189(159-206)^{\mathrm{a}}$ & 71 & $189(63-374)^{\mathrm{a}}$ & $62(40-98)^{\mathrm{a}}$ \\
9 & $162.5(154-172)^{\mathrm{b}}$ & 79 & $193(106-440)^{\mathrm{a}}$ & $52.5(39.5-70)^{\mathrm{b}}$ \\
12 & $46.5(41.5-54.5)^{\mathrm{c}}$ & 100 & $253(140-623)^{\mathrm{a}, \mathrm{b}}$ & $48.5\left(39.5-655^{\mathrm{b}, \mathrm{c}}\right.$ \\
17 & $27(23-29.5)^{\mathrm{d}}$ & 88 & $446.5(180-682)^{\mathrm{c}, \mathrm{d}}$ & $42(34-59)^{\mathrm{d}, \mathrm{e}}$ \\
21 & $18.5(16.5-20)^{\mathrm{e}}$ & 100 & $426.5(182-576)^{\mathrm{b}, \mathrm{d}, \mathrm{d}}$ & $45.5(25-58.5)^{\mathrm{c}, \mathrm{d}}$ \\
25 & $13.5(12.5-16.5)^{\mathrm{f}}$ & 88 & $493(177-1553)^{\mathrm{d}}$ & $44(27.5-59)^{\mathrm{d}, \mathrm{e}}$ \\
30 & $12(10-14)^{\mathrm{g}}$ & 67 & $288(146-410)^{\mathrm{a}, \mathrm{b}, \mathrm{c}}$ & $41(25-55)^{\mathrm{e}}$ \\
\hline
\end{tabular}

Table 2. Salinity-dependant development of tomonts of Ichthyophthirius multifiliis $(\mathrm{n}=24)$ incubated at $12^{\circ} \mathrm{C}$ at different salinity levels. Values are expressed as mean with range in parentheses. Different superscripts indicate significant differences using Tukey's analysis $(\mathrm{P}<0.05)$.

\begin{tabular}{|c|c|c|c|c|c|c|}
\hline $\begin{array}{l}\text { Salinity } \\
(\mathrm{g} / \mathrm{l})\end{array}$ & $\begin{array}{l}\text { Time from tomont to } \\
\text { theront in hours }\end{array}$ & Tomonts encysted (\%) & $\begin{array}{l}\text { Tomonts with divi- } \\
\text { sions }(\%)\end{array}$ & Viable tomonts (\%) & $\begin{array}{l}\text { Number of theronts } \\
\text { from one tomocyst }\end{array}$ & $\begin{array}{l}\text { Length of theronts } \\
\qquad(\mu \mathrm{m})\end{array}$ \\
\hline 0 & $53(43-59)^{\mathrm{a}}$ & 83 & 29 & 83 & $282(122-789)^{\mathrm{a}}$ & $55(40.5-69.5)^{\mathrm{a}}$ \\
\hline 1 & $49(39-59)^{\mathrm{a}}$ & 92 & 29 & 92 & $166(37-315)^{\mathrm{a}, \mathrm{b}}$ & $53(36-70.5)^{\mathrm{a}, \mathrm{b}}$ \\
\hline 3 & $97(74-122)^{\mathrm{b}}$ & 50 & 50 & 33 & $79(48-96)^{\mathrm{b}}$ & $49.5(39-70)^{b}$ \\
\hline 5 & - & 29 & 54 & 0 & - & - \\
\hline 7.5 & - & - & - & - & - & - \\
\hline
\end{tabular}

Table 3. Salinity-dependant development of tomonts of Ichthyophthirius multifiliis $(\mathrm{n}=24)$ incubated at $17^{\circ} \mathrm{C}$ at different salinity levels. Values are expressed as mean with range in parentheses. Different superscripts indicate significant differences using Tukey's analysis $(\mathrm{P}<0.05)$.

\begin{tabular}{|c|c|c|c|c|c|c|}
\hline $\begin{array}{l}\text { Salinity } \\
(\mathrm{g} / \mathrm{l})\end{array}$ & $\begin{array}{l}\text { Time from tomont to } \\
\text { theront in hours }\end{array}$ & Tomonts encysted $(\%)$ & $\begin{array}{l}\text { Tomonts with divi- } \\
\text { sions }(\%)\end{array}$ & Viable tomonts $(\%)$ & $\begin{array}{l}\text { Number of theronts } \\
\text { from one tomocyst }\end{array}$ & $\begin{array}{l}\text { Length of theronts } \\
\qquad(\mu \mathrm{m})\end{array}$ \\
\hline 0 & $25.5(22.5-28)^{\mathrm{a}}$ & 100 & 0 & 100 & $398(202-569)^{\mathrm{a}}$ & $45(35.5-55.5)^{\mathrm{a}}$ \\
\hline 1 & $25(20.5-28.5)^{\mathrm{a}}$ & 96 & 4 & 96 & $452(295-657)^{\mathrm{a}}$ & $46(36-55.5)^{\mathrm{a}}$ \\
\hline 3 & $43.5(74-122)^{\mathrm{b}}$ & 75 & 25 & 50 & $204(134-291)^{\mathrm{b}}$ & $38.5(30.5-46.5)^{\mathrm{b}}$ \\
\hline 5 & - & 33 & 58 & 0 & - & - \\
\hline 7.5 & - & - & - & - & - & - \\
\hline
\end{tabular}

Table 4. Mean (range) abundance of Ichthyophthirius multifiliis on different body regions of rainbow trout sampled from 5 farms. Values are expressed as mean with range in parentheses. Different superscripts indicate significant differences using Tukey's analysis $(\mathrm{P}<0.05)$.

\begin{tabular}{lccccc}
\hline Farm & Dorsal & Ventral & Lateral right & Lateral left & Total \\
\hline 1 & $7.8(2-11)$ & $3.6(2-5)$ & $5.0(2-7)$ & $4.2(1-6)$ & $5.2(1-11)$ \\
2 & $3.4(0-9)$ & $0.4(0-1)$ & $3.4(0-7)$ & $2.0(0-3)$ & $2.3(0-9)$ \\
3 & $0.4(0-1)$ & $0.2(0-1)$ & $0.2(0-1)$ & $0.8(0-2)$ & $0.4(0-2)$ \\
4 & $1.6(0-4)$ & $1.4(0-3)$ & $2.4(0-5)$ & $0.8(0-2)$ & $1.6(0-5)$ \\
5 & $16.6(6-29)$ & $2.8(2-4)$ & $9.4(5-12)$ & $11.2(2-18)$ & $10.0(2-29)$ \\
\hline Mean & $6.0(0-29)^{\mathrm{a}}$ & $1.7(0-5)^{\mathrm{b}}$ & $4.1(0-12)^{\mathrm{a}, \mathrm{b}}$ & $3.8(0-18)^{\mathrm{a}, \mathrm{b}}$ & $3.9(0-29)$ \\
\hline
\end{tabular}

For viable tomonts, the mean time to theront release was significantly different between all salinities at $12^{\circ} \mathrm{C}$ (oneway ANOVA: $\mathrm{F}_{2,6}=12.071, \mathrm{P}=0.008$ ) and at $17^{\circ} \mathrm{C}$ (oneway ANOVA: $\left.\mathrm{F}_{2,6}=119.001, \mathrm{P}<0.001\right)$ There was no significant difference between tomonts exposed to $1 \mathrm{~g} / \mathrm{l}$ and controls, but release took significantly longer in tomonts exposed to $3 \mathrm{~g} / \mathrm{l}$ (Table 2, 3).

Theront production from viable tomonts was significantly different between salinities at $12^{\circ} \mathrm{C}$ (one-way ANOVA: $\mathrm{F}_{2,46}=8.895, \mathrm{P}=0.001$ ) and at $17^{\circ} \mathrm{C}$ (one-way ANOVA: $\left.\mathrm{F}_{2,56}=29.172, \mathrm{P}<0.001\right)$. Theront production was not significantly different between tomonts exposed to $1 \mathrm{~g} / 1$ and con- trols, but was significantly lower in tomonts exposed to $3 \mathrm{~g} / \mathrm{l}$ at $12^{\circ} \mathrm{C}$ (Table 2) and $17^{\circ} \mathrm{C}$ (Table 3). Theronts were largest in the control groups and significantly decreased in size with an increasing salinity at $12^{\circ} \mathrm{C}$ (Table 2 ) and $17^{\circ} \mathrm{C}$ (Table 3 ).

\section{Detection of Ichthyophthirius multifiliis}

There was a significant difference in the mean parasite abundance between settlement sites (one-way ANOVA: $\mathrm{F}_{3,70}=2.972, \mathrm{P}=0.038$ ). Mean parasite abundance was highest on the dorsal part of the fish, which was significantly higher than the ventral part, but not between the lateral sides (Table 4). 
Table 5. Range of time (h) for the development of Ichthyophthirius multifiliis from trophont to theront release. Comparison of the present results with literature data. Adapted from Aihua and Buchmann (2001).

\begin{tabular}{ccccc}
\hline Temperature $\left({ }^{\circ} \mathrm{C}\right)$ & Present study & $\begin{array}{c}\text { Aihua and Buchmann } \\
(2001)\end{array}$ & Bauer (1958) & Wagner $(1960)$ \\
\hline 5 & $159-206$ & $192-228$ & 144 & $168-192$ \\
$7-9$ & $154-172$ & $84-108$ & $72-84$ & $48-120$ \\
$10-12$ & $42-55$ & $46-58$ & $36-40$ & $48-60$ \\
17 & $23-29$ & $23.5-35.5$ & $23-26$ & 24 \\
$20-21$ & $16-21$ & $18.5-23.5$ & $18-20$ & 18 \\
25 & $13-17$ & $16-27.5$ & $14-15$ & - \\
30 & $10-14$ & $16-25$ & - & - \\
\hline
\end{tabular}

\section{DISCUSSION}

The time from tomont settlement to theront release for our isolate of Ichthyophthirius multifiliis is shorter than that of other isolates (Bauer 1958, Wagner 1960, Aihua and Buchmann 2001), especially at $\geq 25^{\circ} \mathrm{C}$ (Table 5). Development time-temperature relationships determine timing of repeat treatments to maximise efficacy and interrupt the parasite's life cycle. Our data confirm that different isolates of I. multifiliis have life cycles that differ sufficiently to adjust treatment timing.

Timing of repeat applications at different temperatures significantly alters the efficacy of a treatment regime (Lahnsteiner and Weismann 2007). If all free-living stages are killed by a treatment, the time from trophont exit until theront release is used as the treatment interval. At $17^{\circ} \mathrm{C}$ and $21^{\circ} \mathrm{C}$ the treatment intervals for our isolate are 23 and 16 hours, respectively. Tomonts, however, are more resistant to chemical treatments than theronts (Heinecke and Buchmann 2009, Forwood et al. 2014). Sodium percarbonate (SPC) is also less effective at lower temperatures: $\mathrm{SPC}$ at $128 \mathrm{mg} / \mathrm{l}$ for $1 \mathrm{~h}$ at $17^{\circ} \mathrm{C}$ is $100 \%$ effective against all free-living life stages of our isolate of I. multifiliis, but is only $50 \%$ effective against tomonts at $12{ }^{\circ} \mathrm{C}$ (Forwood et al. 2014). Strategic treatment at lower temperatures requires each cohort of tomonts to be treated at least twice, with a second pair of strategic treatments at the time from trophont exit until theront release to maximally disrupt the life cycle. Treatments at $12^{\circ} \mathrm{C}$ should be applied 12,42 and 54 hours after the initial treatment. Some reinfection will occur, but this treatment pattern maximises efficacy. Treatment, however, is rarely required at $12{ }^{\circ} \mathrm{C}$ (M.L. - unpubl. data).

Theront production in our isolate of I. multifiliis was highest at $25^{\circ} \mathrm{C}$. In a Danish I. multifiliis isolate, Aihua and Buchmann (2001) found higher mean production of theronts per tomocyst than we observed in our isolate at all temperatures except $25^{\circ} \mathrm{C}$. Theront production per tomocyst ranges from 64 (MacLennan 1937) to 3000 (Wagner 1960) and is influenced by the age and size of tomonts (Ewing et al. 1986) and temperature (Aihua and Buchmann 2001). The optimum range for theront production of the Australian isolate is $17-25^{\circ} \mathrm{C}$ and production was significantly reduced at $4{ }^{\circ} \mathrm{C}$ and $30^{\circ} \mathrm{C}$. A Danish isolate produced most theronts at $12-21^{\circ} \mathrm{C}$ and was also inhibited at $5^{\circ} \mathrm{C}$ and $30^{\circ} \mathrm{C}$ (Aihua and Buchmann 2001). This variation may reflect the higher average water temperatures en- countered on Australian trout farms compared to European farms. We observed that low theront production was associated with tomonts dividing prior to undergoing encystment at low $\left(4{ }^{\circ} \mathrm{C}\right)$ and high $\left(30^{\circ} \mathrm{C}\right)$ temperatures. Few of these daughter tomonts were viable and formed tomocysts, and those that did were smaller and produced fewer theronts than normal tomocysts. This probably reflects physiological changes outside the temperature tolerance range of the parasite.

Salinity had a significant effect on the viability of the Australian isolate of I. multifiliis at $3 \mathrm{~g} / \mathrm{l}$ and above and completely prevented theront production at $5 \mathrm{~g} / \mathrm{l}$. Wagner (1960) and Aihua and Buchmann (2001) reported that theront production continued at $5 \mathrm{~g} / 1$ salinity but production occurred over a longer period than at lower salinity. Aihua and Buchmann (2001) observed tomocyst formation at $7.5 \mathrm{~g} / \mathrm{l}$ and Wagner (1960) reported survival and theront production at $10 \mathrm{~g} / \mathrm{l}$ after 63 hours. Mifsud and Rowland (2008) reported effective control of I. multifiliis infecting silver perch Bidyanus bidyanus (Mitchell) in Australia using 2-3 g/l sodium chloride. Direct comparisons of isolates are difficult to make due to differences in experimental design, but these results indicate that Australian isolates are probably more sensitive to salinity than other isolates. The sensitivity of the Australian isolate to salinity has treatment and prevention applications where sodium chloride use is feasible, such as in small volume recirculation systems.

Management of I. multifiliis relies on early detection of the parasite to facilitate decision making, such as whether to treat, based on the temperature and re-infection. Microscopic examination of skin scrapes is routinely used on trout farms for I. multifiliis monitoring. We found that the dorsal region of rainbow trout had the highest abundance of I. multifiliis. Hines and Spira (1973) reported a higher abundance of I. multifiliis on the dorsal part of mirror carp experimentally infected with I. multifiliis. The dorsal region is probably the preferred settlement site for I. multifiliis and that the dorsal part of the fish is the most informative part of the fish to sample when monitoring I. multifiliis.

Our Australian isolate of I. multifiliis reproduces more rapidly but is more sensitive to salinity than other described isolates. Molecular analysis would complement the ecological profiles and further characterise this Australian isolate and provide further points of comparison to other geographical isolates. Assessing development time from settlement to exit from the host at different temperatures 
is also required to compliment the life cycle-temperature relationships for the free-living stages, to maximise capacity to strategically time treatments.

Acknowledgements. We are grateful to the Department of Primary Industries, Victoria for supporting the project and to the staff at Snobs Creek Hatchery in Snobs Creek, Victoria for providing and transporting fish. The Victorian Trout Growers Association (VTGA) and its members provided access and logistical support during the project. This project was supported by funding from the Fisheries Research and Development Corporation (Project 211/255) on behalf of the Australian Government. All procedures were approved by the Flinders University Animal Welfare Committee (Permit E376).

\section{REFERENCES}

Ainua L., Buchmann K. 2001: Temperature and salinity-dependent development of a Nordic strain of Ichthyophthirius multifiliis from rainbow trout. J. Appl. Ichthyol. 17: 273-276.

Ashburner L.D. 1976: Fish diseases and potential fish diseases in Australia. Anim. Quarantine 5: 1-7.

BAUER O.N. 1958: Biologie und Bekämpfung von Ichthyophthirius multifiliis Fouquet. Z. Fisch. Hilfswissenschaft. 7: 575-581.

Buschkiel A.L. 1910: Beiträge zur Kenntnis des Ichthyophthirius multifiliis Fouquet. Arch. Protistenkd. 21: 61-102.

Butcher A.D. 1947: Ichthyophiriasis in Australian trout hatchery. Prog. Fish-Cult. 9: 21-26.

Dickerson H.W., Clark T.G. 1996: Immune response of fishes to ciliates. Ann. Rev. Fish Dis. 6: 107-120.

Dickerson H.W., DAwE D.L. 1995: Ichthyophthirius multifiliis and Cryptocaryon irritans (phylum Ciliphora). In: P.T.K. Woo (Ed.), Fish Diseases and Disorders. Cambridge University Press, Cambridge, pp. 181-226.

EwIng M.S., Lynn M.E., EwING S.A. 1986: Critical periods in development of Ichthyophthirius multifiliis (Ciliophora) populations. J. Protozool. 33: 388-391.

Forwood J.F., Harris J.O. Landos M., Deveney M.R. 2014 Minimum effective concentrations of formalin and sodium percarbonate on the free-living stages of an Australian isolate of Ichthyophthirius multifiliis. Parasitol. Res. 113: 3251-3258.

Heinecke R.D., Buchmann K. 2009: Control of Ichthyophthirius multifiliis using a combination of water filtration and sodium percarbonate: dose-response studies. Aquaculture 288: 32-35.

Hines R.S., SPIRA D.T. 1973: Ichthyophthirius multifiliis (Fouquet) in the mirror carp. I. Course of infection. J. Fish Biol. 5: 385-392.
Lahnsteiner F., Weismann T. 2007: Treatment of ichthyophthiriasis in rainbow trout and common carp with common and alternative therapeutics. J. Aquat. Anim. Hlth. 19: 186-194.

MaCLENNAN R.F. 1937: Growth in the ciliate Ichthyophthirius multifiliis. 1. Maturity and encystment. J. Exp. Zool. 76: 423-440

Matthews R.A. 2005: Ichthyophthirius multifiliis Fouquet and ichthyophthiriosis in freshwater teleosts. Adv. Parasitol. 59: 159-241.

Mifsud C., Rowland S.J. 2008: Use of salt to control ichthyophthiriosis and prevent saprolegniosis in silver perch, Bidyanus bidyanus. Aquacult. Res. 39: 1175-1180.

Nigrelli R.F., Pokorny K.S., Ruggieri G.D. 1976: Notes on Ichthyophthirius multifiliis, a ciliate parasitic on fresh-water fishes, with some remarks on possible physiological races and species. Trans. Am. Microsc. Soc. 95: 607-613.

Noe G.J., Dickerson H.W. 1995: Sustained growth of Ichthyophthirius multifiliis at low temperature in the laboratory. J. Parasitol. 81: 1022-1024.

Picón-Camacho S.M., Marcos-Lopez M., Bron J.E., Shinn A.P. 2012: An assessment of the use of drug and non-drug interventions in the treatment of Ichthyophthirius multifiliis Fouquet, 1876, a protozoan parasite of freshwater fish. Parasitology 139: 149-190.

SCHÄPERClaus W. 1992: Diseases caused by ciliates. In W. Schäperclaus, H. Kulow and K. Schreckenbach (Eds.), Fish Diseases. CRC Press, Rotterdam, pp. 702-734.

WAGNer G. 1960: Der Entwicklungszyklus von Ichthyophthirius multifiliis Fouquet und der Einfluss physikalischer und chemischer Aussenfaktoren. Z. Fisch. 9: 425-443.

Cite this article as: Forwood J.M., Harris J.O., Landos M., Deveney M. R. 2015: Life cycle and settlement of an Australian isolate of Ichthyophthirius multifiliis Fouquet, 1876 from rainbow trout. Folia Parasitol. 62: 013. 